\title{
A small molecular fluorescent sensor functionalized silica microsphere for detection and removal of mercury, cadmium, and lead ions in aqueous solutions
}

Ding Yu, Weiping Zhu*, Yufang Xu, Xuhong Qian

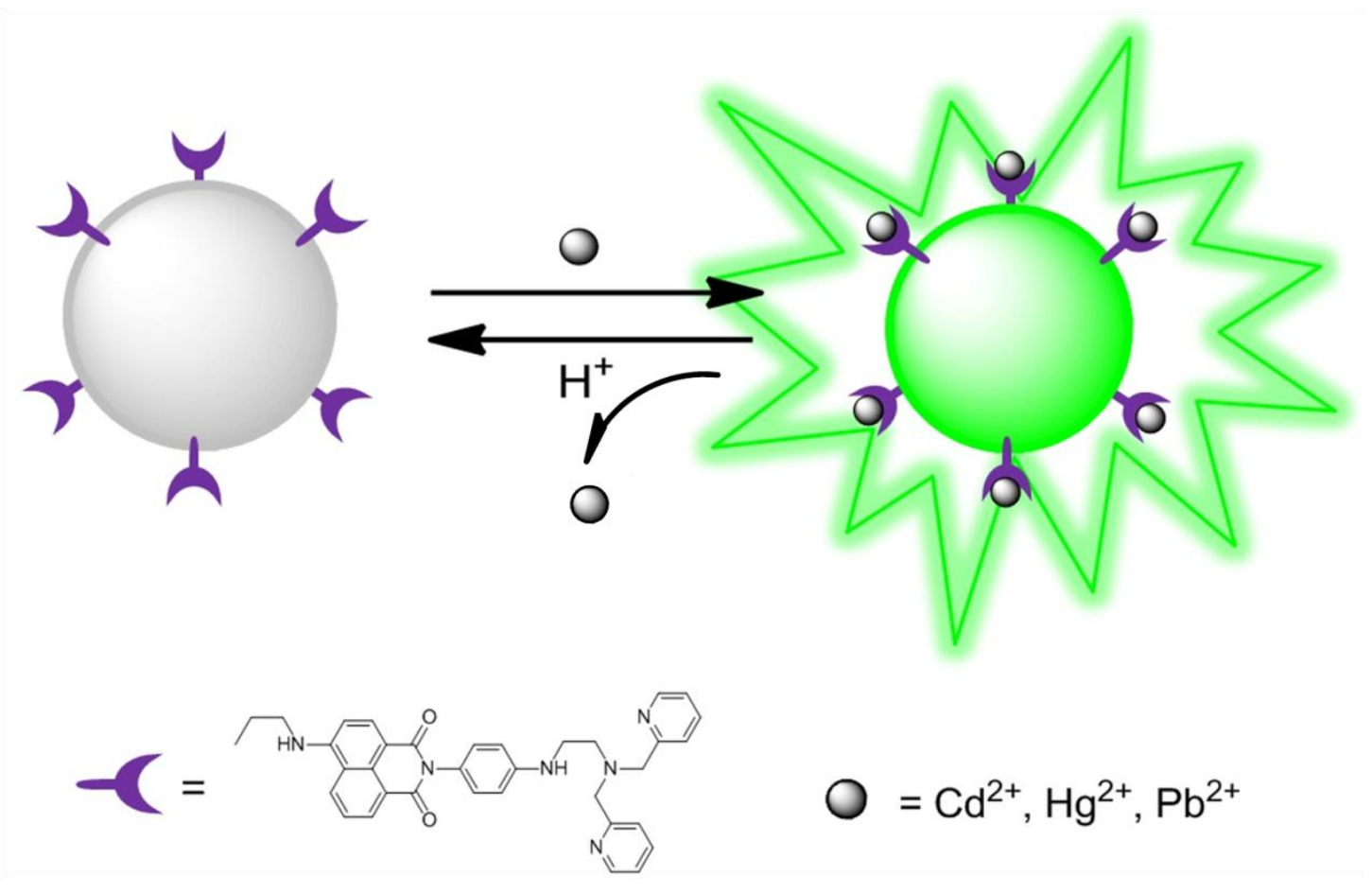




\section{A Small Molecular Fluorescent Sensor Functionalized Silica Microsphere for Detection and Removal of Mercury, Cadmium, and Lead Ions in Aqueous Solutions}

Yu Ding, Weiping Zhu*, Yufang Xu, Xuhong Qian

State Key Laboratory of Bioreactor Engineering, Shanghai Key Laboratory of Chemical Biology, School of Pharmacy, East China University of Science and Technology, Shanghai 200237, China

* To whom correspondence should be addressed

E-mail: wpzhu@ecust.edu.cn 


\section{Abstract}

In this paper, we report a sensitive fluorescent sensor (FSCHP) for detection and removal of toxic metal ions $\left(\mathrm{Cd}^{2+}, \mathrm{Hg}^{2+}\right.$ and $\left.\mathrm{Pb}^{2+}\right)$ in aqueous samples. FSCHP is a 2,2-dipicolylamine (DPA) modified naphthalimide fluorophore followed by immobilization to the surface of silica microsphere and support high affinity for $\mathrm{Cd}^{2+}$, $\mathrm{Hg}^{2+}$ and $\mathrm{Pb}^{2+}$. Metal adsorption by FSCHP was featured by an enhancement in its fluorescence intensity. The limit of detection of $36 \mathrm{nM}$ for $\mathrm{Cd}^{2+}, 48 \mathrm{nM}$ for $\mathrm{Hg}^{2+}$, and $39 \mathrm{nM}$ for $\mathrm{Pb}^{2+}$, was measured respectively. Moreover, FSCHP can also be used as adsorbent for the separation of toxic metal ions in the contaminated aqueous solution with high adsorptivity, and can be regenerated by acid treatment. The metal ion removal capacity of FSCHP was retained after five removal/regeneration cycles.

\section{Keywords:}

Fluorescent sensor; Heavy metal ions; Detection; Removal; Reusable 


\section{Introduction}

Cadmium, mercury, and lead are naturally occurring toxic heavy metals in air, water and soil $[1,2]$, they are not biodegradable, and accumulate in the environment. These toxic metals enter human body through contaminated food or water, and cause damages to the cardiovascular system, the nervous system, the immune system and organs including kidney, lungs, liver, etc. [3-7] Therefore, the heavy metal pollution has attracted intensive attention since last century [3]. The Food and Agriculture Organization (FAO), Environmental Protection Agency (EPA) and World Health Organization (WHO) have regulated the concentration limits of these metals in food and drinking water $[2,4]$.

Sensitive detection of heavy metals plays a key role in the control of heavy metal pollution, atomic absorption spectrometry [5] and inductively coupled plasma mass spectrometry [6] are the most common methods used to detect toxic metals (Cadmium, Lead and Mercury). On the other hand, removal of toxic metals from contaminated water is necessary to remedy the heavy metal pollutions. Nowadays, some techniques have been developed to separate toxic metals from various samples, such as, redox co-precipitation, chemical deposition, ion displacement, membrane filtering, absorption technique and solid-phase extraction [7-14].

Fluorometry is a convenient method for simply, accurately and rapidly tracking metal ions in biological and environmental samples [2, 15-17]. In recent years, small molecule fluorescent probes for heavy metal ions have flourished in detection of metal ions. However, they are incapable of removing of heavy metal ions upon 
recognition due to their diffusive nature. Therefore, immobilization of a small molecule probe to a solid surface to prepare heterogeneous fluorescent sensors has been an ongoing interest of the field [18-25]. Previously, we reported a bifunctional fluorescent sensor for sensing and separating $\mathrm{Hg}^{2+}$ [26], it can detect trace mercury ions in aqueous sample, and can be used as an adsorbent to remove mercuric ions from contaminated aqueous sample. Herein, we report our recent progress in improvement of the detection sensitivity, adsorptivity and regeneration capability of new bifunctional fluorescent sensor.

With good affinity to $\mathrm{Zn}^{2+}, 2,2$-dipicolylamine (DPA) unit and its derivatives have been the most widely used receptors for zinc ions since 1996 [27]. DPA and its derivatives can also chelate with various heavy metal ions and have been harnessed by some fluorescent sensors to detect $\mathrm{Cd}^{2+}, \mathrm{Pb}^{2+}$ or $\mathrm{Cu}^{2+}[28-34]$. We envisage that DPA derivatives might be a versatile receptor for heavy metal ions, which can be used to develop a fluorescent sensor for detect and remove these ions. In this work, we have prepared a novel heterogeneous reusable assembly (FSCHP) for detection/removal of toxic metal ions, i.e. mercury, cadmium, and lead ions, by conjugate ion, N,N'-bis(pyridin-2-ylmethyl)ethane-1,2-diamine modified naphthalimide fluorophore onto the surface of silica microsphere. 


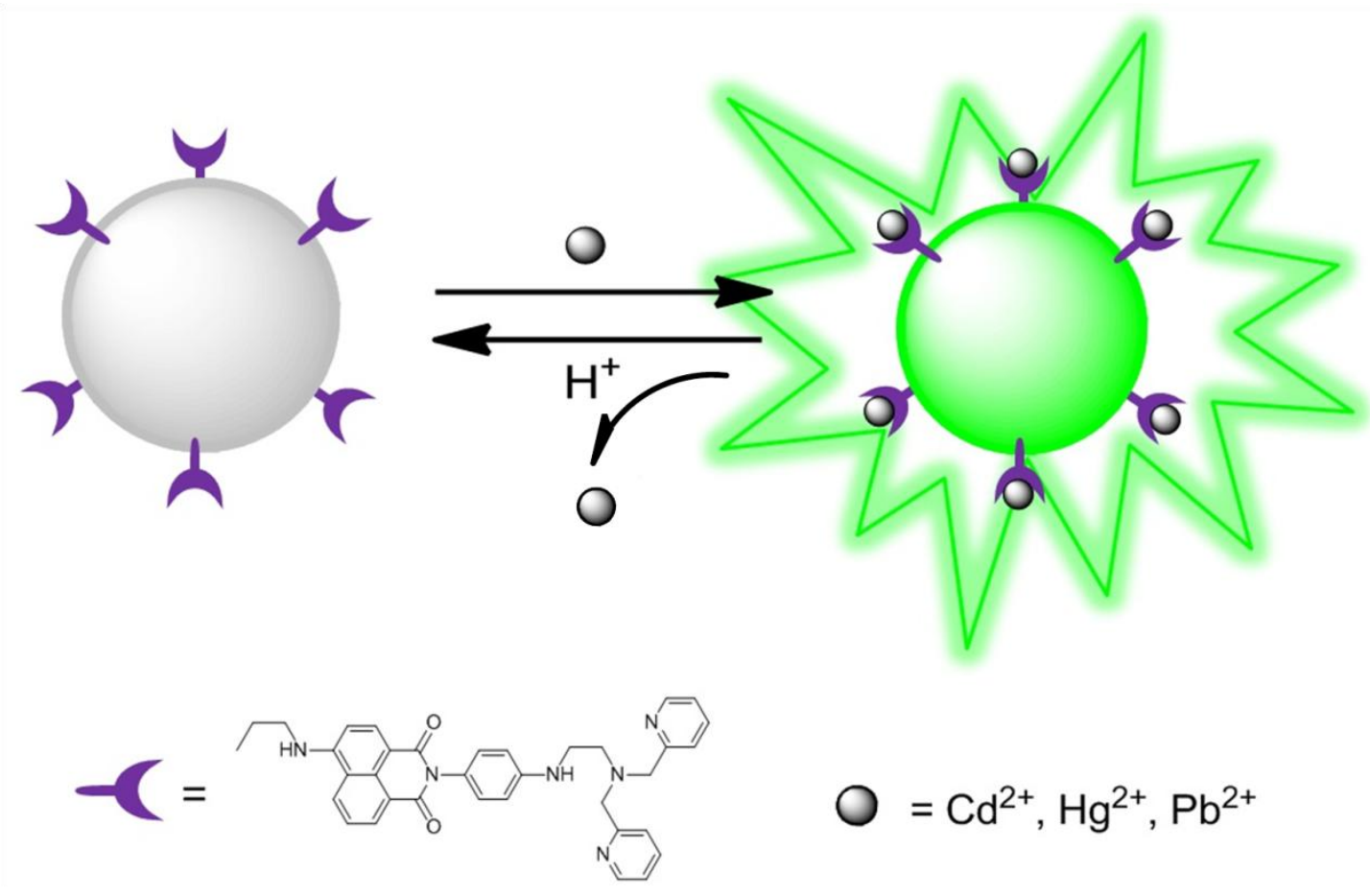

Scheme 1. Plausible mechanism of bifunctional fluorescent sensor FSCHP for the detection and removal of toxic metal ions.

\section{Experimental}

\subsection{Materials and instruments}

Dimethylformamide were purified by reduced pressure distillation; other solvents were purchased from TCI Co or J\&K Co. Tetraethoxysilane (TEOS); aminopropyltriethoxysilane was purchased from TCI Co. ${ }^{1} \mathrm{H}$ NMR spectra; ${ }^{13} \mathrm{C}$ NMR spectra were recorded in $\mathrm{CDCl}_{3}$ at $25{ }^{\circ} \mathrm{C}$ on a Bruker $\mathrm{AV}-400$ spectrometer. All pH titration were carried out by using a pH-Meter PB-10. Elemental analysis was analyzed with a Germany Elementar Vario EL III. Concentrations of metal ions were determined by a Varian 710ES Inductively Coupled Plasma Atomic Emission Spectrometry (ICP-AES). 
SEM images of the microsphere were taken by Hitachi S-520 scanning electron microscopy to assess the size and shape of the microsphere samples. Dynamic light scattering (DLS) was measured by an ALV/CGS-5022F from ALV Ltd. (German).

\subsection{Preparation}

The synthetic route of bifunctional fluorescent sensor FSCHP is depicted in Scheme 2.

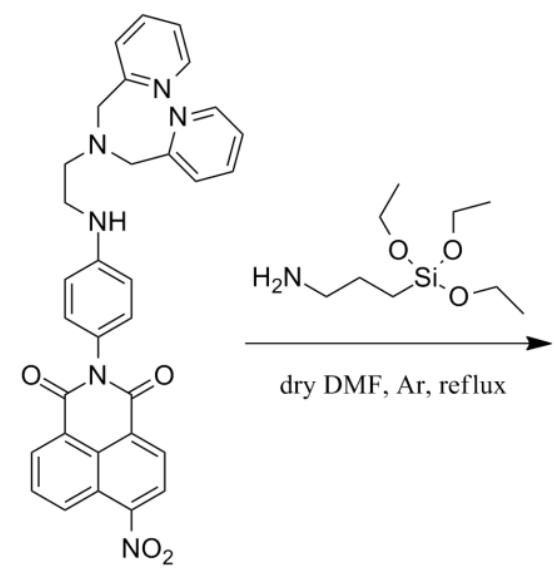

2

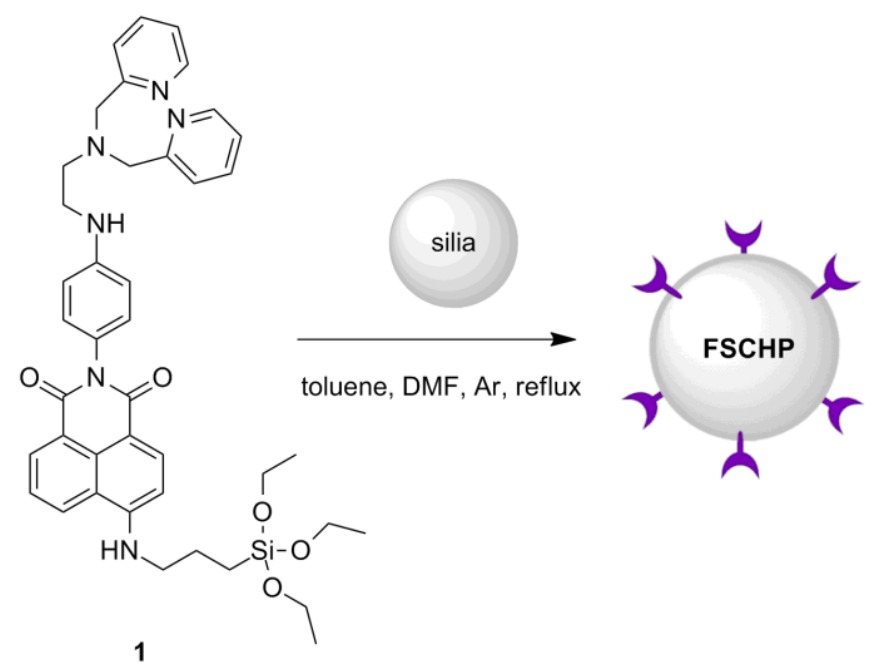

Scheme 2. Preparation of bifunctional fluorescent sensor FSCHP.

\subsubsection{Synthesis of compound 1}

Compound 2 (100 mg, $0.179 \mathrm{mmol}$ ) and aminopropyltriethoxysilane (38 mg, 0.172 mmol) were dissolved in $5 \mathrm{~mL}$ of anhydrous $\mathrm{DMF}$ and heated to $60{ }^{\circ} \mathrm{C}$ for $1 \mathrm{~h}$ under nitrogen atmosphere. Then the solvent was removed by rotary evaporation and the residue was directly purified by flash column chromatography (silica gel, $\mathrm{CH}_{2} \mathrm{Cl}_{2} / \mathrm{CH}_{3} \mathrm{OH}=30 / 1$, v/v) to provide $1(50 \mathrm{mg}, 38.3 \%)$ as the yellow powder. m.p. $>300{ }^{\circ} \mathrm{C} .{ }^{1} \mathrm{H}$ NMR $\left(400 \mathrm{MHz}, \mathrm{CDCl}_{3}, 25{ }^{\circ} \mathrm{C}\right): \delta 8.60(\mathrm{~d}, J=7.2 \mathrm{~Hz}, 1 \mathrm{H}), 8.56(\mathrm{~d}$, 
$J=4.8 \mathrm{~Hz}, 2 \mathrm{H}), 8.25(\mathrm{~d}, J=8.4 \mathrm{~Hz}, 1 \mathrm{H}), 8.17(\mathrm{~d}, J=8.8 \mathrm{~Hz}, 1 \mathrm{H}), 7.61 \sim 71(\mathrm{~m}, 3 \mathrm{H})$, $7.45(\mathrm{~d}, J=8.0 \mathrm{~Hz}, 2 \mathrm{H}), 7.16(\mathrm{t}, J=6.0 \mathrm{~Hz}, 2 \mathrm{H}), 7.05(\mathrm{~d}, J=8.4 \mathrm{~Hz}, 2 \mathrm{H}), 6.73(\mathrm{~d}, J=$ $8.4 \mathrm{~Hz}, 2 \mathrm{H}), 6.77$ (d, J = 8.4 Hz, 2H), 5.77 (br, 1H, -NH-), 3.92 (br, 1H, -NH-), 3.91 (s, 4H), $3.87(\mathrm{q}, J=7.2 \mathrm{~Hz}, 6 \mathrm{H}), 3.83 \sim 3.88(\mathrm{~m}, 2 \mathrm{H}), 3.20(\mathrm{t}, J=5.6 \mathrm{~Hz}, 2 \mathrm{H}), 2.90(\mathrm{t}, J=$

$5.6 \mathrm{~Hz}, 2 \mathrm{H}), 1.91 \sim 1.98(\mathrm{~m}, 2 \mathrm{H}), 1.26(\mathrm{t}, J=7.2 \mathrm{~Hz}, 9 \mathrm{H}), 0.82(\mathrm{t}, J=8.0 \mathrm{~Hz}, 2 \mathrm{H}) .{ }^{13} \mathrm{C}$ NMR (100 MHz, $\left.\mathrm{CDCl}_{3}, 25{ }^{\circ} \mathrm{C}\right): \delta 166.31,164.73,159.13,149.72,149.11,148.42$, $136.62,134.79,131.38,130.29,129.13,126.24,124.93,124.53,123.56,123.26$, $122.24,120.43,113.06,110.32,104.25,60.34,58.65,53.43,52.83,45.75,41.71$, 22.10, 18.33, 7.92. IR (KBr, $\left.\mathrm{cm}^{-1}\right):$ 3375, 2925, 1656, 1582, 1363, 1260, 1112, 910. HRMS (EI): calculated for 732.3455, found 732.3450. Compound 2 was prepared according to the reported procedure [35].

\subsubsection{Synthesis of silica microsphere}

The silica microsphere was prepared via a modified Stöber-Van Blaaderen method [36, 37]. TEOS (1 mL, $2.7 \mathrm{mmol})$ in aqueous solution $(10 \mathrm{~mL})$ was added to ammonia solution $(50 \mathrm{~mL}, 1 \%)$ slowly for $5 \mathrm{~h}$ in a $35^{\circ} \mathrm{C}$ thermostated vessel. After stirring for $8 \mathrm{~h}$, the reaction mixture was centrifugated to remove the remaining reagents. The particles were washed with $75 \%$ alcohol and ultrapure water. IR $(\mathrm{KBr}$, $\left.\mathrm{cm}^{-1}\right): 3650,3415,1050,760$.

\subsubsection{Preparation of the fluorescent sensor $(\boldsymbol{F S C H P})$}

Compound 1 (37 mg, $0.05 \mathrm{mmol}$ ) and as-synthesized silica microsphere (activated in vacuum drier at $130{ }^{\circ} \mathrm{C}$ for $24 \mathrm{~h}$ ) were added to a solution of toluene (20 mL) and DMF (5 mL). The mixture was stirred and refluxed for $24 \mathrm{~h}$ under argon atmosphere. 
After that, the microsphere was washed and centrifugated for at least five times, until the UV/Vis spectrum of the supernate showed the absence of absorption in 300 $\mathrm{nm} \sim 800 \mathrm{~nm}$. The fluorescent sensor FSCHP was then obtained, and elemental analysis revealed $\mathrm{C}$ and $\mathrm{N}$ of $35 \mathrm{mg}$ and $6.0 \mathrm{mg}$ per $1 \mathrm{~g}$ of FSCHP, respectively. IR $\left(\mathrm{KBr}, \mathrm{cm}^{-1}\right): 3415,2950,1645,1560,1363,1100,750$.

\subsection{Fluorescence detection of $\mathrm{Cd}^{2+}, \mathrm{Pb}^{2+}$ and $\mathrm{Hg}^{2+}$ by $\mathbf{F S C H P}$}

$\mathrm{Hg}\left(\mathrm{ClO}_{4}\right)_{2} \cdot 3 \mathrm{H}_{2} \mathrm{O}, \mathrm{Cd}\left(\mathrm{ClO}_{4}\right)_{2} \cdot 6 \mathrm{H}_{2} \mathrm{O}$ and $\mathrm{Pb}\left(\mathrm{ClO}_{4}\right)_{2} \cdot 3 \mathrm{H}_{2} \mathrm{O}$ were of analytical grade, and the stock solutions of different metal ions were prepared with ultrapure water.

The concentration of 1 was calculated to be $3.6 \times 10^{-5} \mathrm{M}$ for a suspension of $5 \mathrm{mg}$ of the FSCHP in $10 \mathrm{~mL}$ of water solution. After FSCHP $(5 \mathrm{mg})$ was suspended in aqueous solution $(10 \mathrm{~mL})$, the emission spectra of the suspension with different concentrations of $\mathrm{Cd}^{2+}, \mathrm{Pb}^{2+}$ and $\mathrm{Hg}^{2+}$ were obtained upon excitation at $450 \mathrm{~nm}$. All the measurements were repeated three times and the general average was obtained.

\subsection{Adsorption of $\mathrm{Cd}^{2+}, \mathrm{Pb}^{2+}$ and $\mathrm{Hg}^{2+}$}

Adsorption capacity of FSCHP was investigated by following steps: a $5 \mathrm{mg}$ of FSCHP was mixed in $10 \mathrm{~mL}$ of aqueous solution with different concentrations of $\mathrm{Cd}^{2+}, \mathrm{Hg}^{2+}$ and $\mathrm{Pb}^{2+}$ in centrifuge tubes. After the mixture was dispersed by mechanically shaking for several seconds at room temperature, the tubes were centrifuged for $5 \mathrm{~min}$ in centrifuge and $1 \mathrm{~mL}$ of supernatant was pipetted to measure the concentration of metal ions. The adsorption capacity of FSCHP was then calculated.

The equilibrium adsorption capacity $\left(\mathrm{Q}_{\mathrm{e}}, \mathrm{mg} / \mathrm{g}\right)$ and the adsorptivity (the percentage 
of metal ions removed from the solution) can be calculated by the following equations:

$$
\begin{gathered}
\mathrm{Q}_{\mathrm{e}}=\frac{\left(\mathrm{C}_{0}-\mathrm{C}_{\mathrm{e}}\right) \mathrm{V}}{\mathrm{m}} \\
\text { adsorptivity }=\frac{\left(\mathrm{C}_{0}-\mathrm{C}_{\mathrm{e}}\right)}{\mathrm{C}_{0}} \times 100 \%
\end{gathered}
$$

Where $\mathrm{C}_{0}\left(\mathrm{mg} \mathrm{L}^{-1}\right)$ and $\mathrm{C}_{\mathrm{e}}\left(\mathrm{mg} \mathrm{L}^{-1}\right)$ are the initial and equilibrium concentrations of toxic heavy metal ions, respectively. $\mathrm{V}(\mathrm{L})$ is the solution volume and $\mathrm{m}(\mathrm{g})$ is the mass of the adsorbent.

\section{Results and discussion}

\subsection{Characterization of microspheres}

FSCHP was prepared by immobilization of the silanized small molecular probe as a precursor onto the surface of silica microspheres. The form of the FSCHP microspheres was examined by Scanning Electron Micrographs (SEM). FSCHP particles were spherical in shape (Fig. 1) with an average diameter of $c a .0 .8 \mu \mathrm{m}$ (Fig. S1, analyzed by dynamic light scattering).

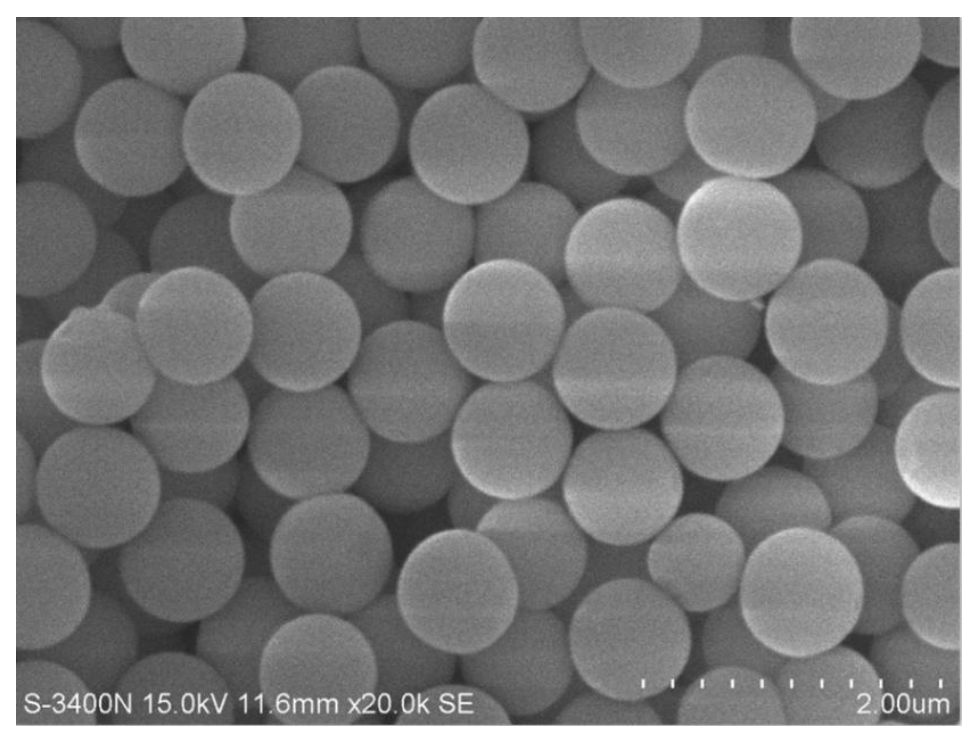

Fig. 1. Scanning electron micrograph of FSCHP. 


\subsection{Fluorescence properties of $\mathbf{F S C H P}$}

The fluorescence stability against acidity is an important property of a sensor [38]. As shown in Fig. 2, the fluorescence of FSCHP was minimal in basic environment presumably due to PET mechanism. A fluorescence enhancement was observed when the solution $\mathrm{pH}$ go below $c a$. 3. At this point, the electron donating nitrogen atoms are all protonated and the PET processes are inhibited. It shows that the property of FSCHP will not be affected in a wide range of $\mathrm{pH}(\mathrm{pH} 3 \sim 10)$.

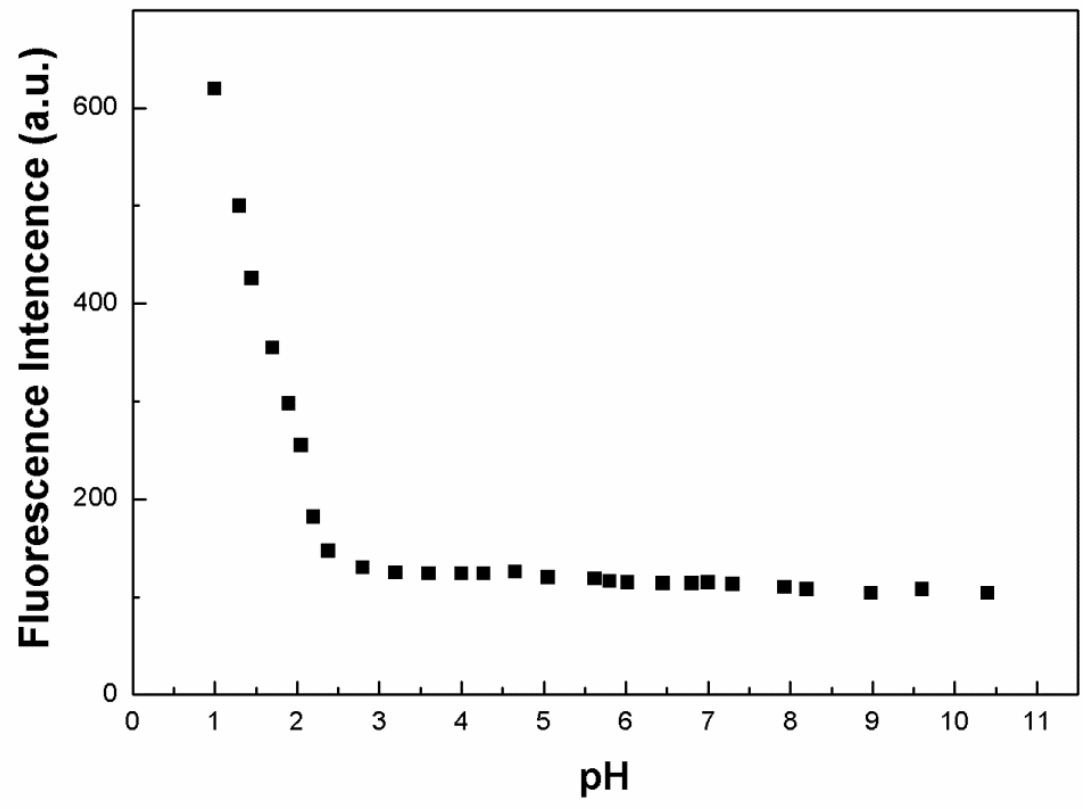

Fig. 2. Changes of fluorescence intensity of FSCHP under different pH (adjusted by

$1 \mathrm{M} \mathrm{HCl}$ or $1 \mathrm{M} \mathrm{NaOH}$ ) in water solution. Conditions: [FSCHP] $=0.5 \mathrm{mg} \mathrm{mL}^{-1}, \lambda_{\mathrm{ex}}$ $=450 \mathrm{~nm}, \lambda_{\mathrm{em}}=550 \mathrm{~nm}, 25^{\circ} \mathrm{C}$, water.

The signal responses of FSCHP toward $\mathrm{Cd}^{2+}, \mathrm{Pb}^{2+}$ and $\mathrm{Hg}^{2+}$ were shown in Fig. 3 . 
With the addition of metal ions $\left(\mathrm{Cd}^{2+}, \mathrm{Pb}^{2+}\right.$ or $\left.\mathrm{Hg}^{2+}\right)$, the fluorescence intensity increased linearly in low concentrations of metal ions. The FSCHP exhibited 4.6-fold fluorescence enhancement upon $\mathrm{Cd}^{2+}$. Upon addition of $\mathrm{Cd}^{2+}(0 \sim 10 \mu \mathrm{M})$, the fluorescence intensity of FSCHP almost increased linearly (Fig. 3b). The limit of detection $[26,39]$, was found to be $3.6 \times 10^{-8}$ M. FSCHP have similar property to $\mathrm{Pb}^{2+}$ and $\mathrm{Hg}^{2+}$ (Fig. S3, S4), and the limit of detection is $4.8 \times 10^{-8} \mathrm{M}^{2}$ for $\mathrm{Hg}^{2+}$, and $3.9 \times 10^{-8}$ $\mathrm{M}$ for $\mathrm{Pb}^{2+}$, respectively. The Job's plot showed that the coordination form of $\mathbf{1}$ with

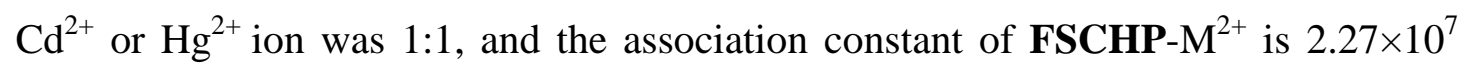
$\mathrm{M}^{-1}$ (for $\mathrm{Cd}^{2+}$ ) or $4.36 \times 10^{7} \mathrm{M}^{-1}$ (for $\mathrm{Hg}^{2+}$ ) [40, 41].
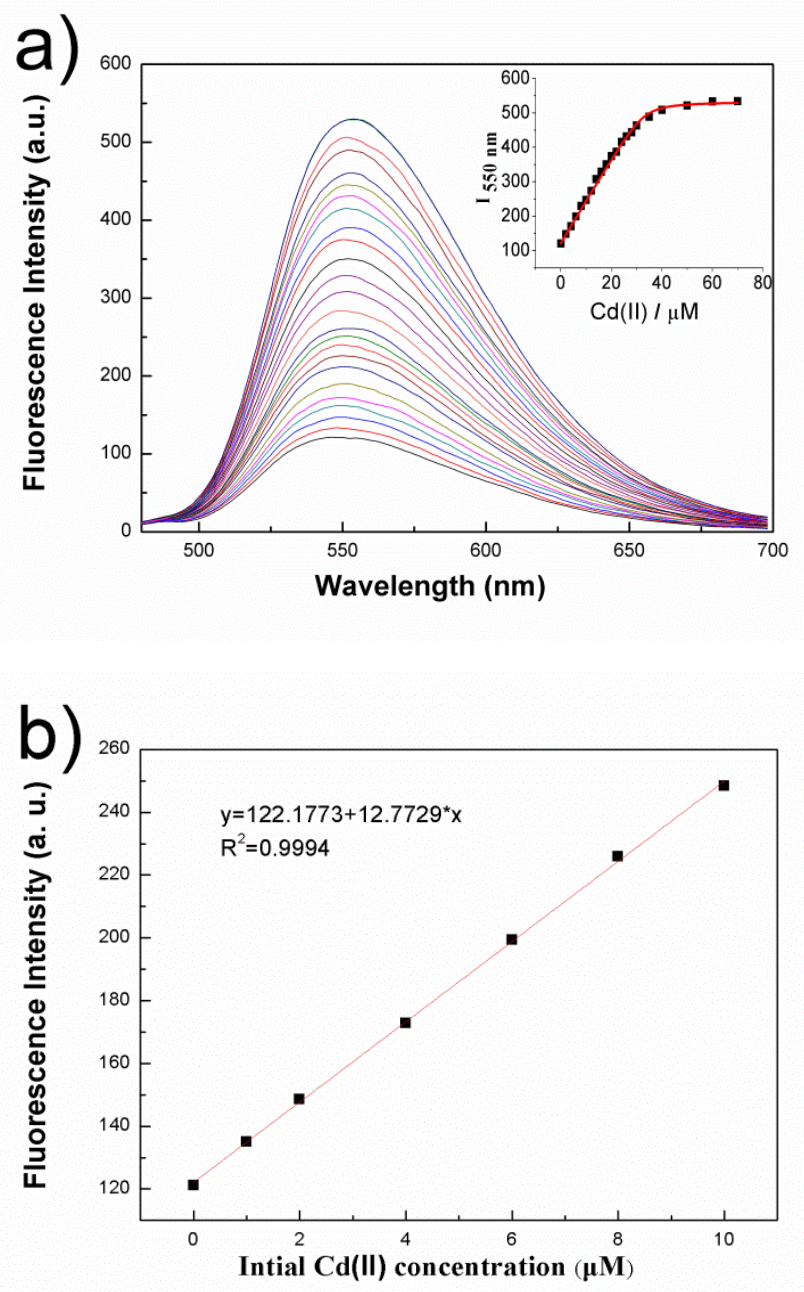
Fig. 3. a) Fluorescence spectra of FSCHP upon addition of Cd(II), Inset: Change of intensity plots of FSCHP vs different concentration of $\mathrm{Cd}(\mathrm{II})$. b) Fluorescence response of FSCHP as a function of $\mathrm{Cd}(\mathrm{II})(0-10 \mu \mathrm{M})$. Condition: [FSCHP] = $0.5 \mathrm{mg} \mathrm{mL}{ }^{-1}, \lambda_{\text {ex }}=450 \mathrm{~nm}, 25^{\circ} \mathrm{C}, \mathrm{pH}=7.0$ (adjusted by $0.1 \mathrm{M}$ Tris- $\mathrm{HCl}$ buffer solution).

\subsection{Adsorption kinetics}

As one of the main properties of newly prepared absorbing material towards the metal ions, the interaction time very important to exhibit the efficiency of absorbing materials [42]. Therefore, we investigated the profile of the adsorption capacity of FSCHP in the different adsorption time. FSCHP (2.5 mg) was added to water solution $(5 \mathrm{~mL})$ containing different concentrations of metal ions $\left(1 \times 10^{-6}\right.$, $\left.1 \times 10^{-5}, 1 \times 10^{-4} \mathrm{M}\right)$ of $\mathrm{Cd}^{2+}, \mathrm{Pb}^{2+}$ or $\mathrm{Hg}^{2+}$, respectively, and the mixed solution was oscillated for different times $(0.5 \sim 3 \mathrm{~min})$. Then the mixture was centrifuged and the supernate was pipetted off for determination of remaining concentration of metal ions. The concentrations of metal ions $\left(\mathrm{Cd}^{2+}, \mathrm{Pb}^{2+}\right.$ and $\left.\mathrm{Hg}^{2+}\right)$ were measured by ICP-AES. As shown in Fig. 4, FSCHP could adsorb $\mathrm{Cd}^{2+}$ very quickly (less than $30 \mathrm{sec}$ ), and there is negligible variation of the FSCHP toward $\mathrm{Cd}^{2+}$ in different adsorption time (0.5 3 min). And similar results were found for $\mathrm{Hg}^{2+}$ and $\mathrm{Pb}^{2+}$ (Fig. S5), respectively. The non-functionalized silica microspheres have no adsorption ability to $\mathrm{Cd}^{2+}, \mathrm{Hg}^{2+}$ and $\mathrm{Pb}^{2+}$ as control. The results demonstrated that FSCHP has high affinity and short response time toward toxic metals ions, which can be used for rapid separation of toxic metals ions from aqueous system. 


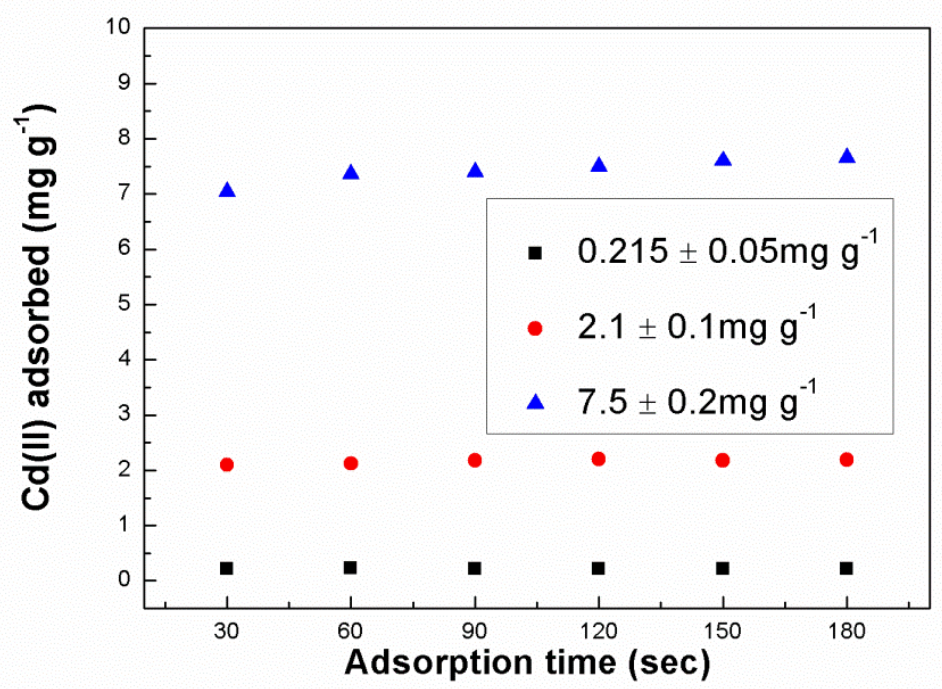

Fig. 4. Effect of adsorption time on Cd(II) adsorption onto FSCHP microspheres (initial metal ion concentration: $1 \times 10^{-6}, 1 \times 10^{-5}, 1 \times 10^{-4} \mathrm{M}, \quad[\mathbf{F S C H P}]=$ $\left.0.5 \mathrm{mg} \mathrm{mL}^{-1}\right) . \mathrm{pH}=7.0$ (adjusted by $0.1 \mathrm{M}$ Tris- $\mathrm{HCl}$ solution).

3.4. Fluorescence response for different initial concentrations of metal ions and adsorption isotherm

The relationship between the fluorescence responses toward metal ions and the adsorptivity of FSCHP is shown in Fig. 5 and Fig. S6. As shown in Fig. 5, as the concentration of cadmium ions increased in the solution, the fluorescence intensity at $550 \mathrm{~nm}$ enhanced by 4.6-fold. Meanwhile, and the adsorption capacity of FSCHP was estimated to be ca. $7.5 \mathrm{mg} / \mathrm{g}$ for $\mathrm{Cd}^{2+}$. Note that we can monitor the equilibrium adsorption capacity of FSCHP from the fluorescence fluctuation. Similar results are shown in Fig. $\mathrm{S} 6$ for $\mathrm{Hg}^{2+}$ and $\mathrm{Pb}^{2+}$ ions, respectively. Besides, the saturated adsorption capacity $\left(\mathrm{Q}_{\max }\right)$ of $\mathrm{Cd}^{2+}$ and $\mathrm{Hg}^{2+}$ were found to be related to the content of compound 1 (from elemental analysis) in FSCHP. That is, the adsorption capacity of 
FSCHP is related to the content of $\mathbf{1}$ onto the surface of FSCHP microsphere. The saturated adsorption capacity $\left(\mathrm{Q}_{\max }\right)$ of FSCHP of $\mathrm{Cd}^{2+}, \mathrm{Hg}^{2+}$ and $\mathrm{Pb}^{2+}$ is shown in Table 1. The data of $\mathrm{Q}_{\max }$ were found at the initial $\mathrm{M}^{2+}$ concentration of $0.1 \mathrm{mM}$.

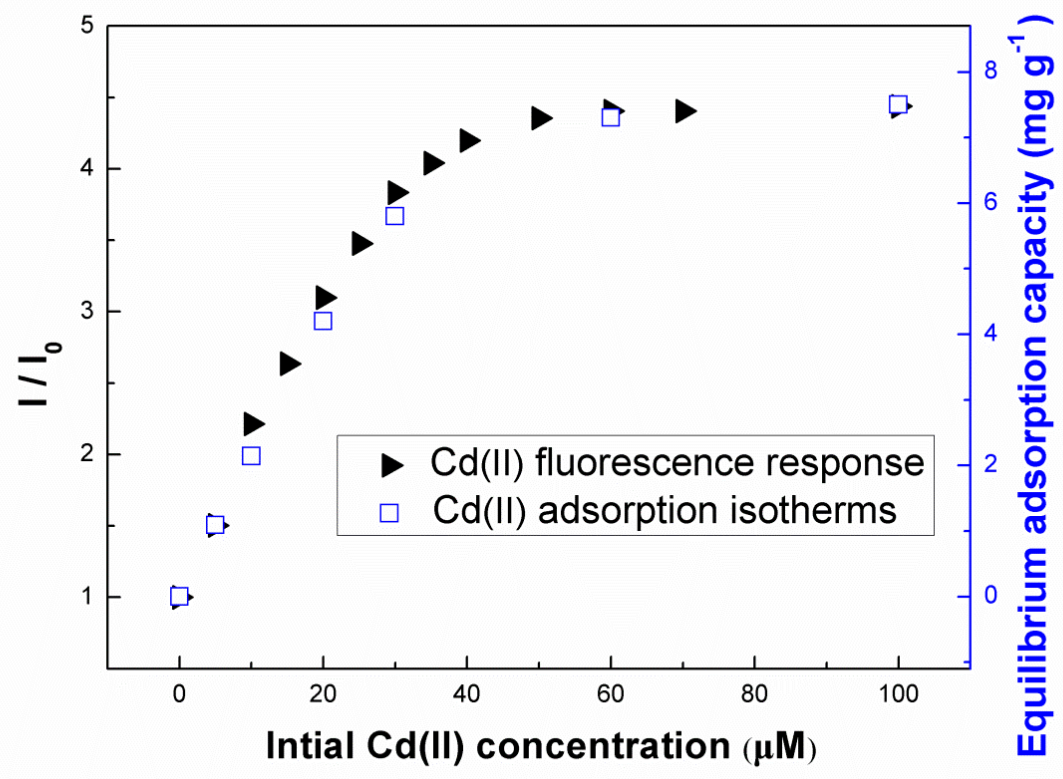

Fig. 5. Adsorption isotherms and fluorescence response of FSCHP microspheres for $\mathrm{Cd}(\mathrm{II})$ ions with different concentrations in water at room temperature. $[\mathbf{F S C H P}]=$ $0.5 \mathrm{mg} \mathrm{mL}^{-1}, \mathrm{pH}=7.0$ (adjusted by $0.1 \mathrm{M}$ Tris- $\mathrm{HCl}$ solution). $\mathrm{I}_{0}$ is the initial fluorescence intensity of this system.

\section{Table 1.}

The saturated adsorption capacity of FSCHP.

\begin{tabular}{llll}
\hline & $\mathrm{Cd}^{2+}$ & $\mathrm{Pb}^{2+}$ & $\mathrm{Hg}^{2+}$ \\
\hline $\mathrm{Q}_{\max }(\mathrm{mg} / \mathrm{g})$ & 7.5 & 11.0 & 14 \\
\hline
\end{tabular}

The change of concentrations of $\mathrm{Cd}^{2+}, \mathrm{Hg}^{2+}$ and $\mathrm{Pb}^{2+}$ ions before and after adsorption with FSCHP was further investigated. As shown in Fig. 6, with the 
increased concentration of $\mathrm{Cd}^{2+}$, the adsorptivity of FSCHP declined significantly, but the equilibrium adsorption capacity enhanced very quickly. When the cadmium ions concentration reduced to $10 \mu \mathrm{M}$, the adsorptivity of FSCHP for $\mathrm{Cd}^{2+}$ reaches to $96 \%$. When the concentration of $\mathrm{Cd}^{2+}$ ions reached to $30 \mu \mathrm{M}$, the equilibrium adsorption capacity raised to $5.8 \mathrm{mg} \mathrm{g}^{-1}$. However, the adsorptivity of FSCHP for cadmium is only $86 \%$. Similar results were found for $\mathrm{Hg}^{2+}$ and $\mathrm{Pb}^{2+}$ ions when FSCHP was used as the adsorbent (Fig. S7). Since the concentration of $\mathrm{Cd}^{2+}, \mathrm{Hg}^{2+}$ and $\mathrm{Pb}^{2+}$ ions in real water samples is very low, a higher adsorptivity can be achieved by use of a small amount of FSCHP $\left(0.5 \mathrm{~g} \mathrm{~L}^{-1}\right)$ when the concentration of toxic metal ions is less than $30 \mu \mathrm{M}$. And when the concentration of metal ions less than $10 \mu \mathrm{M}$, FSCHP can achieve very high adsorptivity (>95\%).

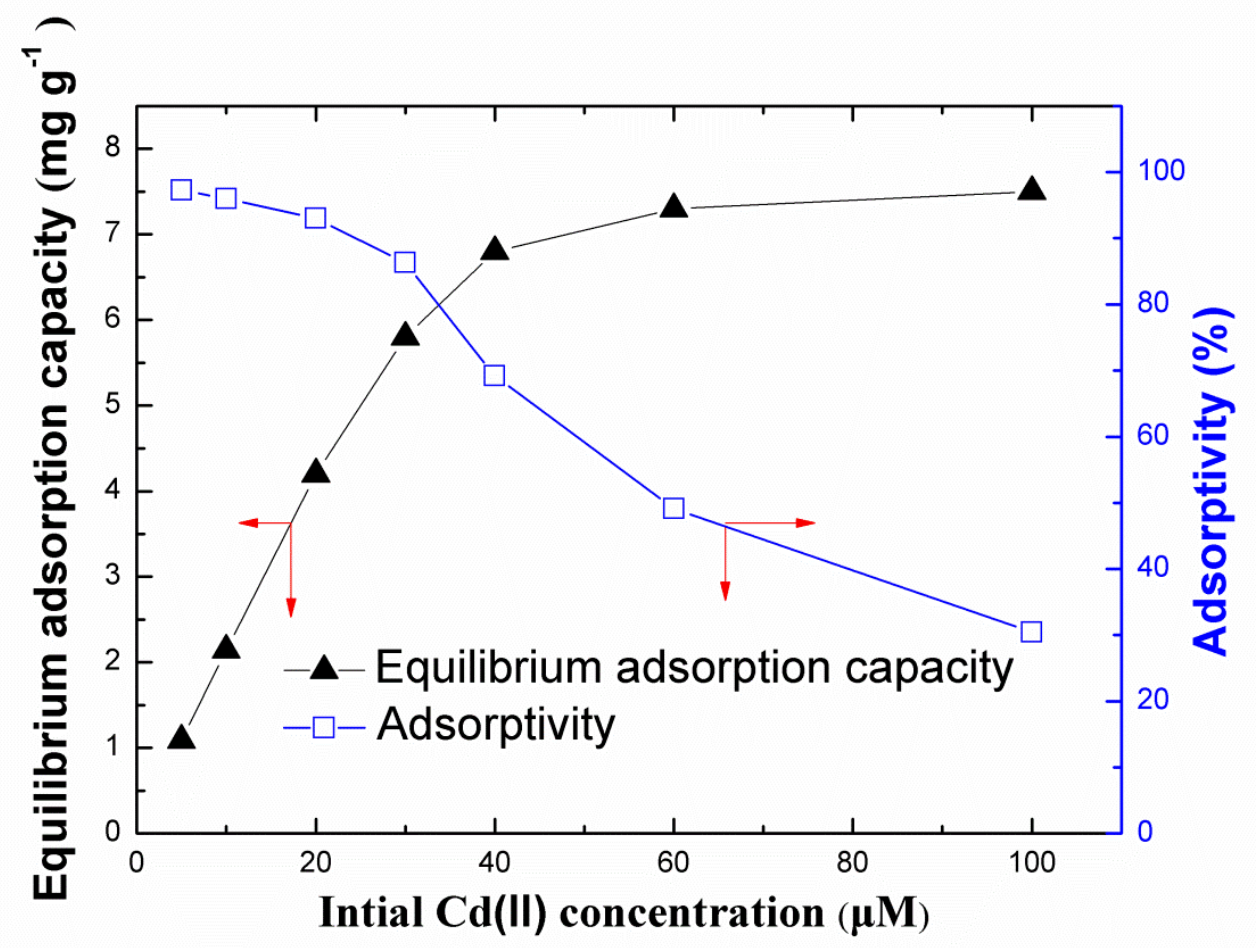

Fig. 6. Adsorption isotherms (the amount of Cd(II) adsorbed by FSCHP $\left(0.5 \mathrm{mg} \mathrm{mL}^{-1}\right)$ 
for different concentrations of Cd(II)) and adsorptivity of FSCHP $\left(0.5 \mathrm{mg} \mathrm{mL}^{-1}\right)$ for different concentrations of $\mathrm{Cd}(\mathrm{II}))$ of FSCHP in water at room temperature. $\mathrm{pH}=7.0$ (adjust by $0.1 \mathrm{M}$ Tris- $\mathrm{HCl}$ solution).

The adsorption behavior of FSCHP for $\mathrm{Cd}^{2+}, \mathrm{Hg}^{2+}$ and $\mathrm{Pb}^{2+}$ was analyzed by Langmuir model, where $\mathrm{Q}_{\max }$ is the saturation adsorption capacity of the material's surface and $b$ is a constant related to the intensity of adsorption[43]:

$$
\frac{\mathrm{C}_{\mathrm{e}}}{\mathrm{Q}_{\mathrm{e}}}=\frac{1}{\mathrm{Q}_{\max } \mathrm{b}}+\frac{\mathrm{C}_{\mathrm{e}}}{\mathrm{Q}_{\max }}
$$

Fitting of $C_{e} / Q_{e}$ against $C_{e}$ showed a straight line in Fig. 7 and Fig. S8. The adsorption isotherm behavior of $\mathrm{Cd}^{2+}, \mathrm{Pb}^{2+}$ or $\mathrm{Hg}^{2+}$ onto FSCHP fits the Langmuir equation well: The model fit parameter $\left(\mathrm{R}^{2}\right)$ was 0.9998 for $\mathrm{Cd}^{2+}, 0.9997$ for $\mathrm{Hg}^{2+}$ and 0.997 for $\mathrm{Pb}^{2+}$, respectively. The calculated parameters $\mathrm{Q}_{\max }$ are consistent with the real saturation adsorption capacity, as is shown in Table 1. 


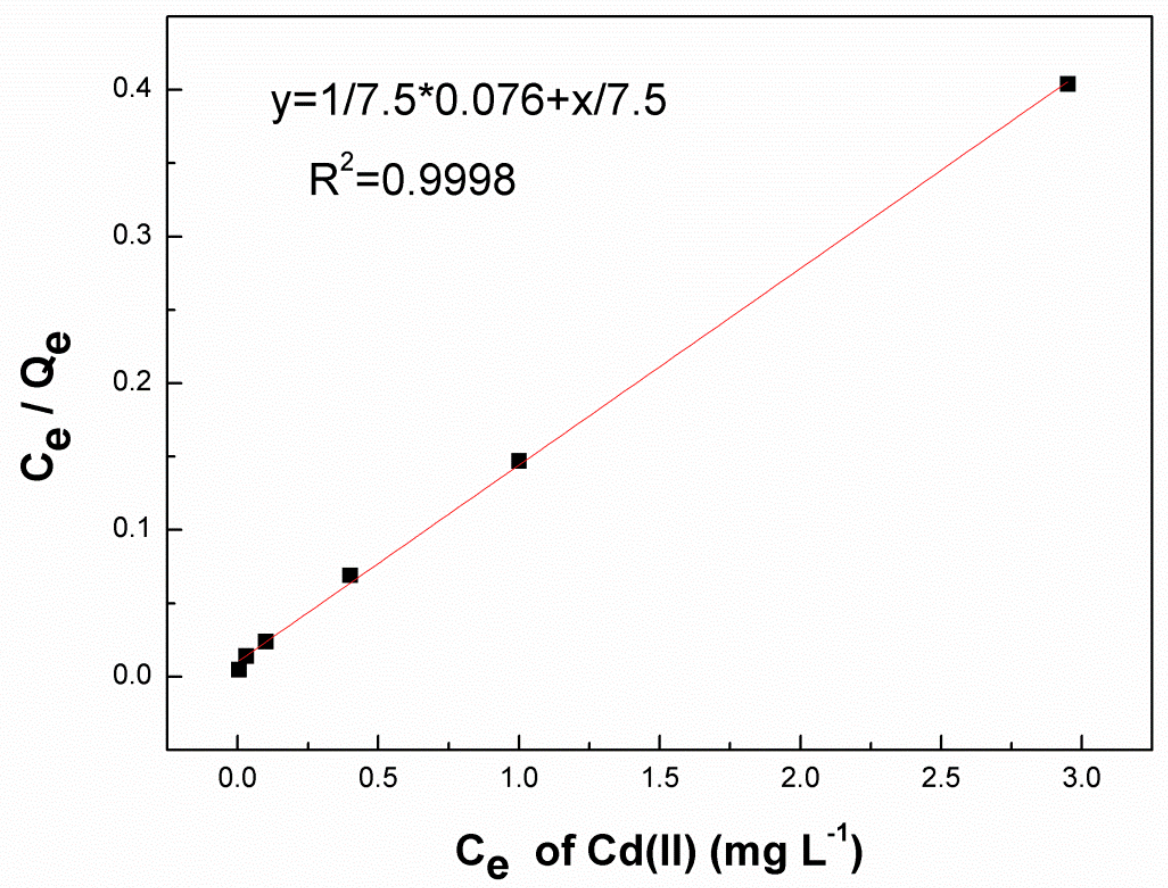

Fig. 7. Langmuir plot for the sorption of Cd(II) using FSCHP.

\subsection{Effect of solution $p H$}

The impact of the solution $\mathrm{pH}$ on the adsorption capacity of the FSCHP microspheres for $\mathrm{Cd}^{2+}, \mathrm{Pb}^{2+}$ and $\mathrm{Hg}^{2+}$ is shown in Fig. 8. FSCHP has a good adsorption capacity for $\mathrm{Cd}^{2+}, \mathrm{Pb}^{2+}$ and $\mathrm{Hg}^{2+}$ ions in the range of $\mathrm{pH} 5 \sim 8$. As the solubility products $\mathrm{pK}_{\mathrm{SP}}$ of $\mathrm{Pb}(\mathrm{OH})_{2}$ are 14.84 , considering the prevention of the precipitation of metal hydroxides, we measure the FSCHP's adsorption capacity for $\mathrm{Pb}^{2+}$ ions at $\mathrm{pH}<5.5[44,45]$. When the solution's $\mathrm{pH}$ is below 4.5 , the adsorption capacity of FSCHP for $\mathrm{Cd}^{2+}, \mathrm{Pb}^{2+}$ and $\mathrm{Hg}^{2+}$ ions reduces rapidly with the decrease of pH. Hence we can desorb the $\mathrm{Cd}^{2+}, \mathrm{Pb}^{2+}$ and $\mathrm{Hg}^{2+}$ from FSCHP microspheres by adjusting the $\mathrm{pH}$ of the water solution. 


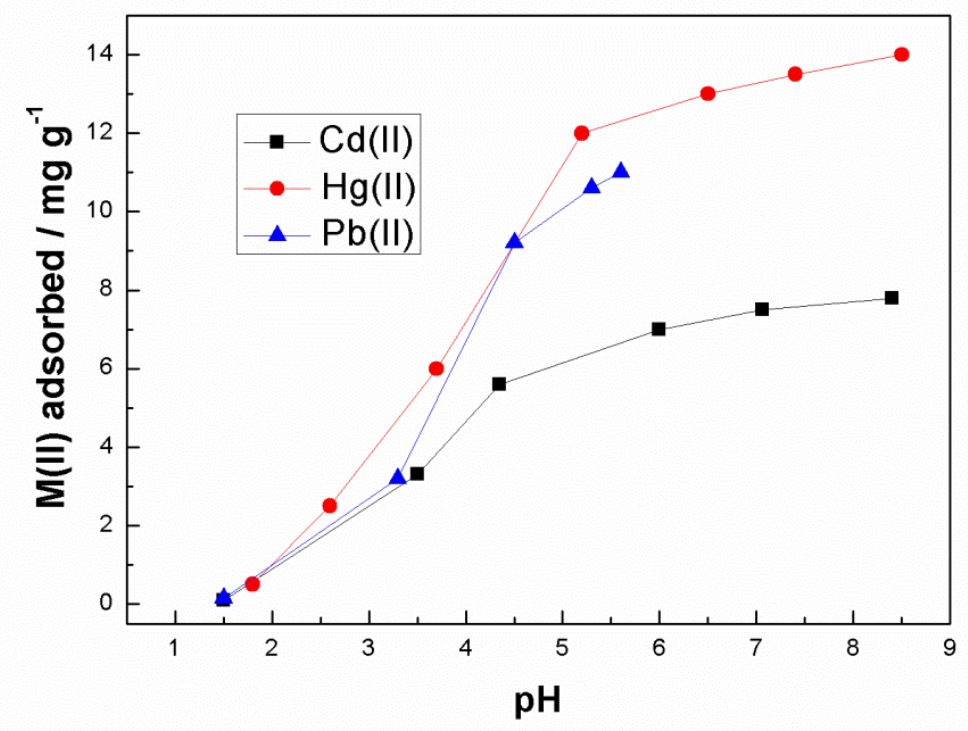

Fig. 8. Effect of solution pH on the adsorption capacity of the FSCHP microspheres for $\mathrm{Cd}(\mathrm{II}), \mathrm{Pb}(\mathrm{II})$ and $\mathrm{Hg}(\mathrm{II}), \mathrm{pH}$ was adjusted by $1 \mathrm{M} \mathrm{HCl}$ solution or $1 \mathrm{M} \mathrm{NaOH}$ solution.

\subsection{Recyclability of FSCHP}

An important requirement for the solid bifunctional sensor for detection and removal of metal ions is its reusability. As shown in Fig. 8, FSCHP has a very low adsorption capacity for cadmium, mercury and lead ions when $\mathrm{pH}<2.0$, so we envision that the FSCHP complexed with $\mathrm{Cd}^{2+}, \mathrm{Pb}^{2+}$ and $\mathrm{Hg}^{2+}$ can be easily desorbed and FSCHP can be regenerated in acidic condition $(\mathrm{pH}<2.0)$. To investigate its reusability, $10 \mathrm{mg}$ of FSCHP microsphere was used to complex $\mathrm{Cd}^{2+}, \mathrm{Pb}^{2+}$ or $\mathrm{Hg}^{2+}$ in a repeated adsorption-desorption fashion. In this test, the stripping agent was $0.1 \mathrm{M}$ $\mathrm{HCl}$ for $\mathrm{Cd}^{2+}, \mathrm{Pb}^{2+}$ and $\mathrm{Hg}^{2+}$. The whole test process included three steps: (1) wash the FSCHP microsphere with stripping agent (5 mL for three times), (2) adjust the $\mathrm{pH}$ value of the mixture system (by using $1 \mathrm{M} \mathrm{NaOH}$ solution. For $\mathrm{Cd}^{2+}, \mathrm{pH}=7.0$; for 
$\mathrm{Hg}^{2+}, \mathrm{pH}=7.0$; for $\mathrm{Pb}^{2+}, \mathrm{pH}=5.5$ ), and (3) fluorescent detection of metal ions. As shown in Fig. 9 and Fig. S9, FSCHP was found to reused after adsorbed $\mathrm{Cd}^{2+}, \mathrm{Pb}^{2+}$ and $\mathrm{Hg}^{2+}$, the complex/stripping cycles can be at least five times, and the decrease of the FSCHP's fluorescence intensity may because of the effect of the mechanical process injury the fluorescence property of FSCHP, and FSCHP must have little lost in the whole regeneration experiments $[26,46]$. In general, FSCHP showed outstanding reusability and stability towards $\mathrm{Cd}^{2+}, \mathrm{Hg}^{2+}$ and $\mathrm{Pb}^{2+}$ within at least five regeneration cycles.

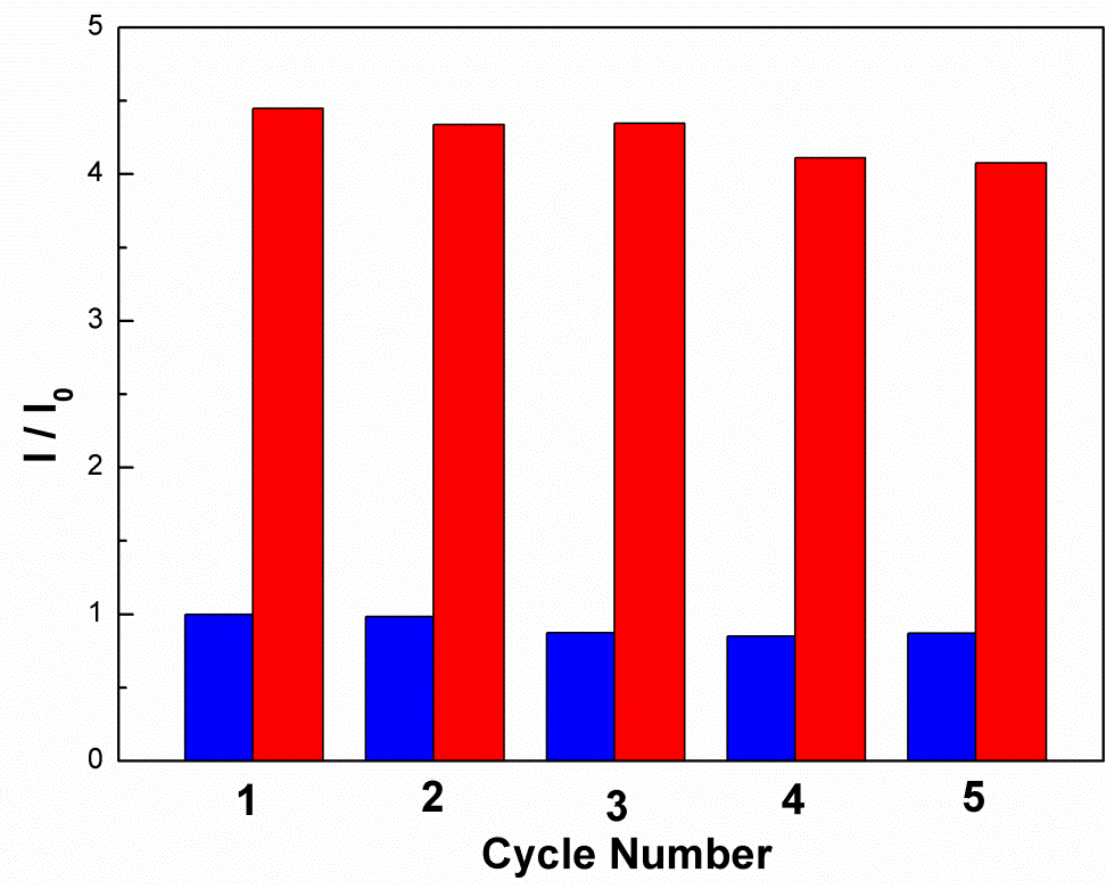

Fig. 9. Fluorescence response of FSCHP $\left(0.5 \mathrm{mg} \mathrm{mL}^{-1}\right)$ in the $1 \times 10^{-4} \mathrm{M}$ of $\mathrm{Cd}$ (II) over five complex/stripping cycles. I corresponds to the emission intensity of FSCHP with cations (red bars), and $\mathrm{I}_{0}$ corresponds to the emission intensity of FSCHP without cations (blue bars), $\lambda_{\mathrm{ex}}=450 \mathrm{~nm}, 25^{\circ} \mathrm{C}$. 


\subsection{Application of FSCHP in water and simulated biological samples}

To investigate the feasibility of FSCHP for the detection and removal of toxic metal ions in real samples, FSCHP was applied to determine the concentration of $\mathrm{Cd}^{2+}, \mathrm{Hg}^{2+}$ and $\mathrm{Pb}^{2+}$ in water samples (tap water and waste water of lab) and simulated biological sample (dilutions of fetal calf serum). As shown in Table 2, the results showed that FSCHP not only is a good fluorescent sensor with actually and experimentally determined concentrations of $\mathrm{Cd}^{2+}, \mathrm{Hg}^{2+}$ and $\mathrm{Pb}^{2+}$, but also is an efficient adsorbent in water and simulated biological samples for $\mathrm{Cd}^{2+}, \mathrm{Hg}^{2+}$ and $\mathrm{Pb}^{2+}$, indicating great potential of FSCHP in the detection and removal of toxic metal ions in environmental and biological samples.

\section{Table 2.}

Determination of $\mathrm{Cd}^{2+}, \mathrm{Hg}^{2+}$ and $\mathrm{Pb}^{2+}$ in water sample and simulated biological background samples.

\begin{tabular}{|c|c|c|c|c|c|c|}
\hline Samples & $\begin{array}{c}\text { Metal } \\
\text { ions }\end{array}$ & $\begin{array}{l}\text { Added, } \\
\mathrm{mg} \mathrm{L}^{-1}\end{array}$ & $\begin{array}{l}\text { Detected } \\
\mathrm{mg} \mathrm{L}^{-1}\end{array}$ & $\begin{array}{c}\text { Recovery } \\
(\%)\end{array}$ & $\begin{array}{c}\text { Adsorbed } \\
\mathrm{mg} \mathrm{L}^{-1}\end{array}$ & $\begin{array}{c}\text { Adsorptivity } \\
(\%)\end{array}$ \\
\hline \multirow[t]{7}{*}{ Tap water } & $\mathrm{Cd}^{2+}$ & 0 & 0 & & 0 & \\
\hline & & 0.5 & $0.50 \pm 0.02$ & 100 & $0.48 \pm 0.02$ & 96 \\
\hline & & 2.0 & $1.98 \pm 0.04$ & 99 & $1.97 \pm 0.05$ & 98.5 \\
\hline & $\mathrm{Hg}^{2+}$ & 0 & 0 & & 0 & \\
\hline & & 0.5 & $0.48 \pm 0.03$ & 96 & $0.49 \pm 0.02$ & 97.5 \\
\hline & & 2.0 & $1.97 \pm 0.05$ & 98.5 & $1.96 \pm 0.04$ & 98.0 \\
\hline & $\mathrm{Pb}^{2+}$ & 0 & 0 & & 0 & \\
\hline
\end{tabular}




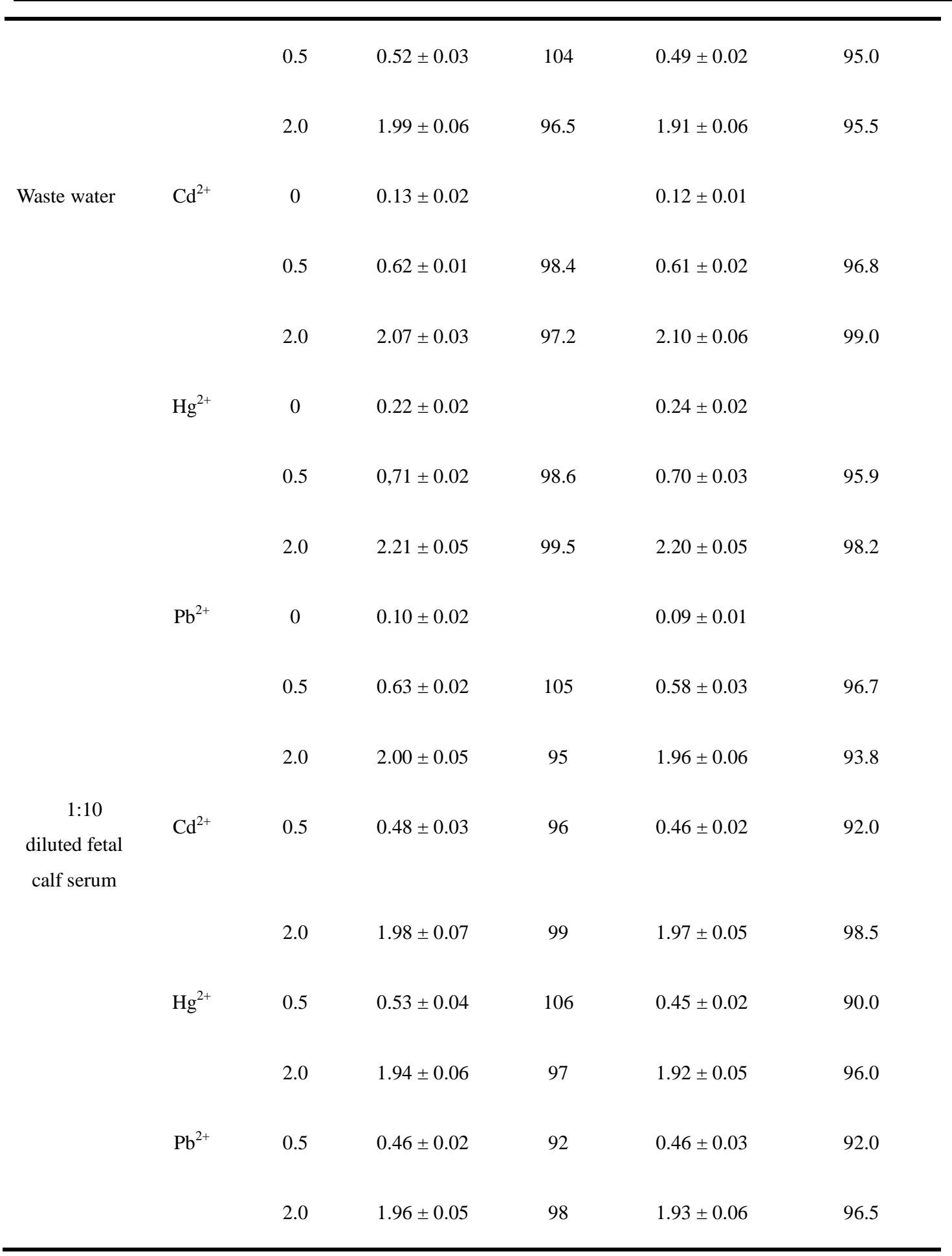

\section{Conclusions}

In conclusion, by using 2,2-dipicolylamine (DPA) derivative as the binding receptor, we have synthesized a new bifunctional fluorescent microsphere sensor FSCHP. 
FSCHP is the first sensor which could be used for both detection and removal of three toxic metal ions $\left(\mathrm{Cd}^{2+}, \mathrm{Hg}^{2+}\right.$ and $\left.\mathrm{Pb}^{2+}\right)$. The detection limit of FSCHP for $\mathrm{Cd}^{2+}$, $\mathrm{Hg}^{2+}$ and $\mathrm{Pb}^{2+}$ were $36 \mathrm{nM}$ for $\mathrm{Cd}^{2+}, 48 \mathrm{nM}$ for $\mathrm{Hg}^{2+}$, and $39 \mathrm{nM}$ for $\mathrm{Pb}^{2+}$, respectively. FSCHP's fluorescence intensity can indicate the equilibrium adsorption capacity of FSCHP in real-time. FSCHP can keep good adsorptivity for $\mathrm{Cd}^{2+}, \mathrm{Pb}^{2+}$ and $\mathrm{Hg}^{2+}$ until the FSCHP's equilibrium adsorption capacity $\left(\mathrm{Q}_{\mathrm{e}}\right)$ is close to the saturated adsorption capacity $\left(\mathrm{Q}_{\max }\right)$, which is $7.5 \mathrm{mg} \mathrm{g}^{-1}$ for $\mathrm{Cd}^{2+}, 14 \mathrm{mg} \mathrm{g}^{-1}$ for $\mathrm{Hg}^{2+}$, and 11.7 $\mathrm{mg} \mathrm{g}^{-1}$ for $\mathrm{Pb}^{2+}$, respectively. Moreover, FSCHP can be regenerated by acid treatment and reused for at least five cycles. In real water samples and simulated biological samples, toxic metal ions can be completely adsorbed by FSCHP at low concentration of $\mathrm{Cd}^{2+}, \mathrm{Hg}^{2+}$ and $\mathrm{Pb}^{2+}$. Thus FSCHP can be used to detect and remove toxic $\mathrm{Cd}^{2+}, \mathrm{Hg}^{2+}$ and $\mathrm{Pb}^{2+}$ pollutants from contaminated environmental and biological samples.

\section{Acknowledgements}

We thank the financial support from the National High Technology Research and Development Program of China (2012AA061601), National Natural Science Foundation of China $(21476077,21236002)$, National Basic Research Program of China (973 Program, 2013CB733700) and Shanghai Pujiang Program.

\section{Notes and reference}

[1] A. Sepúlveda, M. Schluep, F.G. Renaud, M. Streicher, R. Kuehr, C. Hagelüken, et al., A review of the environmental fate and effects of hazardous substances released from electrical and 
electronic equipments during recycling: Examples from China and India, Environmental Impact Assessment Review. 30 (2010) 28-41.

[2] H.N. Kim, W.X. Ren, J.S. Kim, J. Yoon, Fluorescent and colorimetric sensors for detection of lead, cadmium, and mercury ions, Chemical Society Reviews. 41(2012) 3210-3244.

[3] Y. Fang, X. Sun, W. Yang, N. Ma, Z. Xin, J. Fu, et al., Concentrations and health risks of lead, cadmium, arsenic, and mercury in rice and edible mushrooms in China, Food chemistry. 147 (2014) 147-151.

[4] W.H. Organization, Guidelines for drinking-water quality. World Health Organization. 2006.

[5] V. Iyengar, J. Woittiez, Trace elements in human clinical specimens: evaluation of literature data to identify reference values, Clinical chemistry. 34 (1988) 474-481.

[6] A.T. Townsend, K.A. Miller, S. Mclean, S. Aldous, The determination of copper, zinc, cadmium and lead in urine by high resolution ICP-MS, Janalatspectrom. 11 (1998) 1213-1219.

[7] A. Sheoran, V. Sheoran, Heavy metal removal mechanism of acid mine drainage in wetlands: a critical review, Minerals engineering. 19 (2006) 105-116.

[8] S. Matagi, D. Swai, R. Mugabe, A review of heavy metal removal mechanisms in wetlands, Afr J Trop Hydrobiol Fish. 8 (1998) 13-25.

[9] S. Shin, J. Jang, Thiol containing polymer encapsulated magnetic nanoparticles as reusable and efficiently separable adsorbent for heavy metal ions, Chemical Communications. 41 (2007) 4230-4232.

[10] F. Fu, Q. Wang, Removal of heavy metal ions from wastewaters: a review, Journal of Environmental Management. 92 (2011) 407-418.

[11] W. Wan Ngah, L. Teong, M. Hanafiah, Adsorption of dyes and heavy metal ions by chitosan composites: A review, Carbohydrate Polymers. 83 (2011) 1446-1456.

[12] A. Wu, J. Jia, S. Luan, Amphiphilic PMMA/PEI core-shell nanoparticles as polymeric adsorbents to remove heavy metal pollutants, Colloids and Surfaces A: Physicochemical and Engineering Aspects. 384 (2011) 180-185.

[13] Y.-M. Liu, X.-J. Ju, Y. Xin, W.-C. Zheng, W. Wang, J. Wei, et al., A Novel Smart Microsphere with Magnetic Core and Ion-Recognizable Shell for $\mathrm{Pb}^{2+}$ Adsorption and Separation, ACS Applied Materials \& Interfaces. 6 (2014) 9530-9542.

[14] H.Y. Lee, D.R. Bae, J.C. Park, H. Song, W.S. Han, J.H. Jung, A Selective Fluoroionophore Based on BODIPY-functionalized Magnetic Silica Nanoparticles: Removal of $\mathrm{Pb}^{2+}$ from Human Blood, Angewandte Chemie International Edition. 48 (2009) 1239-1243.

[15] A. Fitch, Lead analysis: Past and present, Critical reviews in analytical chemistry. 28 (1998) 267-345.

[16] E.M. Nolan, S.J. Lippard, Tools and tactics for the optical detection of mercuric ion, Chemical reviews. 108 (2008) 3443-3480.

[17] C.-T. Chen, W.-P. Huang, A Highly Selective Fluorescent Chemosensor for Lead Ions, Journal of the American Chemical Society. 124 (2002) 6246-6247.

[18] T. Balaji, S.A. El- Safty, H. Matsunaga, T. Hanaoka, F. Mizukami, Optical sensors based on nanostructured cage materials for the detection of toxic metal ions, Angewandte Chemie. 118 (2006) 7360-7366.

[19] B. Zhu, J. Zhao, H. Yu, L. Yan, Q. Wei, B. Du, Naphthalimide-functionalized $\mathrm{Fe}_{3} \mathrm{O}_{4} @ \mathrm{SiO}_{2}$ 
core/shell nanoparticles for selective and sensitive adsorption and detection of $\mathrm{Hg}^{2+}$, Chemical engineering journal. 219 (2013) 411-418.

[20] X. Cheng, J. Li, X. Li, D. Zhang, H. Zhang, A. Zhang, et al., A highly sensitive sensor based on hollow particles for the detection, adsorption and removal of $\mathrm{Hg}^{2+}$ ions, Journal of Materials Chemistry. 22 (2012) 24102-24108.

[21] E. Palomares, R. Vilar, A. Green, J.R. Durrant, Alizarin complexone on nanocrystalline $\mathrm{TiO}_{2}$ : A heterogeneous approach to anion sensing, Advanced Functional Materials. 14 (2004) 111-115.

[22] V. Polshettiwar, R. Luque, A. Fihri, H. Zhu, M. Bouhrara, J.-M. Basset, Magnetically recoverable nanocatalysts, Chemical reviews. 111 (2011) 3036-3075.

[23] E.S. Cho, J. Kim, B. Tejerina, T.M. Hermans, H. Jiang, H. Nakanishi, et al., Ultrasensitive detection of toxic cations through changes in the tunnelling current across films of striped nanoparticles, Nat Mater. 11 (2012) 978-985.

[24] Q. Meng, X. Zhang, C. He, G. He, P. Zhou, C. Duan, Multifunctional mesoporous silica material used for detection and adsorption of $\mathrm{Cu}^{2+}$ in aqueous solution and biological applications in vitro and in vivo, Advanced Functional Materials. 20 (2010) 1903-1909.

[25] F. Lupo, S. Gentile, F.P. Ballistreri, G.A. Tomaselli, M.E. Fragalà, A. Gulino, Viable route for switching of an engineered silica surface using $\mathrm{Cu}^{2+}$ ions at sub-ppm levels, Analyst. 135 (2010) 2273-2279.

[26] C. He, W. Zhu, Y. Xu, T. Chen, X. Qian, Trace mercury(II) detection and separation in serum and water samples using a reusable bifunctional fluorescent sensor, Analytica chimica acta. 651 (2009) 227-233.

[27] R.P. Haugland, M.T. Spence, I.D. Johnson, Handbook of fluorescent probes and research chemicals, Molecular Probes. 1996.

[28] X. Peng, J. Du, J. Fan, J. Wang, Y. Wu, J. Zhao, et al., A selective fluorescent sensor for imaging $\mathrm{Cd}^{2+}$ in living cells, Journal of the American Chemical Society. 129 (2007) 1500-1501.

[29] K.M. Lee, X. Chen, W. Fang, J.M. Kim, J. Yoon, A dual colorimetric and fluorometric sensor for lead ion based on conjugated polydiacetylenes, Macromolecular rapid communications. 32 (2011) 497-500.

[30] J.Y. Kwon, Y.J. Jang, Y.J. Lee, K.M. Kim, M.S. Seo, W. Nam, et al., A highly selective fluorescent chemosensor for $\mathrm{Pb}^{2+}$, Journal of the American Chemical Society. 127 (2005) 10107-10111.

[31] L. Xue, C. Liu, H. Jiang, Highly sensitive and selective fluorescent sensor for distinguishing cadmium from zinc ions in aqueous media, Organic letters. 11 (2009) 1655-1658.

[32] C. Lu, Z. Xu, J. Cui, R. Zhang, X. Qian, Ratiometric and highly selective fluorescent sensor for cadmium under physiological $\mathrm{pH}$ range: a new strategy to discriminate cadmium from zinc, The Journal of organic chemistry, 72 (2007) 3554-3557.

[33] Z. Xu, K.-H. Baek, H.N. Kim, J. Cui, X. Qian, D.R. Spring, et al., Zn ${ }^{2+}$-triggered amide tautomerization produces a highly $\mathrm{Zn}^{2+}$-selective, cell-permeable, and ratiometric fluorescent sensor, Journal of the American Chemical Society. 132 (2009) 601-610.

[34] Y. Chen, C. Zhu, J. Cen, J. Li, W. He, Y. Jiao, et al., A reversible ratiometric sensor for intracellular $\mathrm{Cu}^{2+}$ imaging: metal coordination-altered FRET in a dual fluorophore hybrid, 
Chemical Communications, 49 (2013) 7632-7634.

[35] J. Wang, Y. Xiao, Z. Zhang, X. Qian, Y. Yang, Q. Xu, A pH-resistant Zn(II) sensor derived from 4-aminonaphthalimide: design, synthesis and intracellular applications, J Mater Chem. 15 (2005) 2836-2839.

[36] W. Stöber, A. Fink, E. Bohn, Controlled growth of monodisperse silica spheres in the micron size range, Journal of colloid and interface science. 26 (1968) 62-69.

[37] K. Nozawa, H. Gailhanou, L. Raison, P. Panizza, H. Ushiki, E. Sellier, et al., Smart control of monodisperse Stöber silica particles: effect of reactant addition rate on growth process, Langmuir. 21 (2005) 1516-1523.

[38] L. Prodi, C. Bargossi, M. Montalti, N. Zaccheroni, N. Su, J.S. Bradshaw, et al., An effective fluorescent chemosensor for mercury ions, Journal of the American Chemical Society. 122 (2000) 6769-6770.

[39] J. Inczedy, T. Lengyel, A. Ure, A. Gelencsér, A. Hulanicki, IUPAC compendium of analytical nomenclature: definitive rules. 1998.

[40] B. Valeur, J. Pouget, J. Bourson, M. Kaschke, N. Ernsting, Tuning of photoinduced energy transfer in a bichromophoric coumarin supermolecule by cation binding, The Journal of Physical Chemistry. 96 (1992) 6545-6549.

[41] J. Bourson, J. Pouget, B. Valeur, Ion-responsive fluorescent compounds. 4. Effect of cation binding on the photophysical properties of a coumarin linked to monoaza-and diaza-crown ethers, The Journal of Physical Chemistry. 97 (1993) 4552-4557.

[42] N. Burham, S. Abdel-Azeem, M. El-Shahat, Separation and determination of trace amounts of zinc, lead, cadmium and mercury in tap and Qaroun lake water using polyurethane foam functionalized with 4-hydroxytoluene and 4-hydroxyacetophenone, Analytica chimica acta. 579 (2006) 193-201.

[43] X. Lu, Q. Yin, Z. Xin, Z. Zhang, Powerful adsorption of silver (I) onto thiol-functionalized polysilsesquioxane microspheres, Chemical Engineering Science. 65 (2010) 6471-6477.

[44] J.G. Speight, Lange's handbook of chemistry. New York. 2005.

[45] R. Sitko, B. Zawisza, E. Talik, P. Janik, G. Osoba, B. Feist, et al., Spherical silica particles decorated with graphene oxide nanosheets as a new sorbent in inorganic trace analysis, Analytica chimica acta. 834 (2014) 22-29.

[46] A. Sayari, S. Hamoudi, Y. Yang, Applications of pore-expanded mesoporous silica. 1. Removal of heavy metal cations and organic pollutants from wastewater, Chemistry of Materials. 17 (2005) 212-216. 
Yu Ding received his Bachelor's degree in Anhui University of Science and Technology in 2012. $\mathrm{He}$ is currently carrying out his graduate work for his Masterate under the guidance of Professor Weiping Zhu in Shanghai Key Laboratory of Chemical Biology, East China University of Science and Technology.

Weiping Zhu received his Bachelor's degree from the National University of Defense and Technology in 1989, and Master's degree from East China University of Science and Technology (ECUST) in 1992. After working at Yangzi Petrochemical Institute of SINOPEC for seven years, he returned and received his PhD degree at ECUST (2004). He spent one year as a visiting scholar in University of California, Los Angeles (2009), and now is a professor at ECUST. His research interests focus on the design and synthesis of fluorescent sensors and smart drug delivery systems. Yufang Xu received her PhD degree in Chemistry from East China University of Science and Technology (ECUST) in 1994. Then she joined in ECUST. From 1999 to 2001 she worked as postdoctoral fellow in Tokyo Medical and Dental University. Her research interests focus on small organic molecules to regulate bioprocesses, including the design and synthesis of fluorescent probes to respond to hypoxia and related enzymes to diagnose and treat related diseases especially in solid tumors.

Xuhong Qian received his BS, MS and PhD degrees from East China University of Science and Technology (ECUST) in 1982, 1985 and 1988, respectively. He became an associate professor (1992) and professor (1995-2000, 2004-present) in ECUST. He was a Chongkong professor in DLUT (2000-2004). He is FRSC (2009) and academician of Chinese Academy of Engineering (2011). His research interest covers certain aspects of bioorganic chemistry and engineering related to dyes and pesticides, e.g. fluorescent sensors and antitumor agents derived from dyes, as well as green insecticides and plant-activators. 